\title{
Global Aspects of Australian Aboriginal Law Systems. A Biological Perspective
}

\author{
Hendrik Gommer (Corresponding author) \\ Assistant Professor Law \& Biology \\ Law school, Tilburg University, Tilburg, Netherlands \\ E-mail: hendrikgommer@hetnet.nl \\ Penelope Swales \\ Arts/Law student \\ Indigenous Studies, Monash University, Melbourne, Australia \\ E-mail: penelope@penelopeswales.com
}

Received: November 1, 2011

doi:10.5539/jpl.v5n1p43
Accepted: November 29, $2011 \quad$ Published: March 1, 2012

URL: http://dx.doi.org/10.5539/jpl.v5n1p43

\begin{abstract}
A new natural law theory was proposed in 'A Biological Theory of Law'. This theory holds that law mirrors properties of genes. Probably the most distinguishing characteristic of a gene is that it can replicate itself ad infinitum (the genetic priority of growth), as long as there are sufficient molecules available that can feed the replication. On top of that a gene is stable and it bears a code that can generate all kinds of biological structures. These biological structures could not evolve if genes did not work together. Genes that work together in a reciprocal way can be successful in spreading and therefore their number will grow.

In essence, biological theory of law is based on fractal patterns. Fractals are objects whose smallest particles have the same structure as the composite whole of these particles. Macro scale patterns mirror micro scale patterns. Consequently, by studying micro scale patterns we can discover forces that drive macro scale patterns.

As was shown in the article The Molecular Concept of Law, by recognizing fractal structures in our empiric reality, we can link very different levels and disciplines and subsequently jump from genes to emotions to law in a systematic manner.

This paper explores the proposal that due to a harsh environment and geographical isolation, the genetic priority of growth was successfully curbed by Australian Aboriginal law to operate indefinitely and sustainably within a finite biosphere. The genetic drive for growth will ultimately exhaust our resources and defeat the genes of many of us if we do not find a way through our law to steer it. Ultimately the dilemma we face on a global scale is the same as that solved on a continental scale by Indigenous Australians. Central to the success of classical Aboriginal law was the ability to use law to curb the genetic property of growth by elaborating the genetic property of reciprocity, and much could be learned from Aboriginal legal systems in facing our own environmental and social dilemmas.
\end{abstract}

Keywords: Genes, Biological law theory, Aboriginal, Sustainable growth, Reciprocity

\section{Introduction}

A new natural law theory was proposed in 'A Biological Theory of Law' (Gommer, 2011). This theory holds that law mirrors properties of genes. Probably the most distinguishing characteristic of a gene is that it can replicate itself, as long as there are sufficient molecules available that can feed the replication. On top of that a gene is stable and it bears a code that can generate all kinds of biological structures (Barnsley et al., 2004). These biological structures could not evolve if genes did not work together. Genes that work together in a reciprocal way can be successful in spreading and therefore their number will grow (Alexander, 1987, 84-88).

In essence, biological theory of law is based on fractal patterns. Fractals are objects whose smallest particles have the same structure as the composite whole of these particles. Macro scale patterns mirror micro scale patterns (Mandelbrot, 1982). Consequently, by studying micro scale patterns we can discover forces that drive macro scale patterns (figure 1). 
This way of thinking is related to evolutionary theory. However, by focusing on the fractal pattern, we can avoid detailed biological discussions on exactly how natural selection takes place which would bog us down or divert us from the main issue. This issue is the link between the properties of genes and basic principles in law. By recognizing fractal structures in our empiric reality, we can link very different levels and disciplines and subsequently jump from genes to emotions to law in a systematic manner.

This paper will explore the proposal that due to a harsh environment and geographical isolation, the genetic priority of growth in numbers was successfully curbed by Australian Aboriginal law to operate indefinitely and sustainably within a finite biosphere. This could have significant implications for a future global community which faces the same issue of finite resources on a global scale. First we will describe in short the essential part of biological law theory, then we will explore Aboriginal culture in the light of this theory and finally we will conclude that some characteristics of Aboriginal law can be helpful in facing contemporary global problems.

\section{Genes as First Movers}

What fractal theory can teach us is that the properties of a generator - and genes can operate as such - can be recognized on various levels in biology, psychology, sociology, anthropology, politics, and law. By studying these properties, we can find basic principles of law. In addition, fractal theory shows us that a simple formula can generate very complex structures in behaviour (Liebovitch, 1998, 108). This idea is confirmed by the growth of different types of bacterial colonies. Bacteria only have about 1,000 genes, but all bacteria species have their own very complex fractal colonies. Genes determine the pattern of the colony - i.e. the consequence of bacterial behaviour - but the colony's structural shape also depends on external factors. If other bacteria are encountered, the structure of the colony will change at the point of contact, and some genes will be switched off (Matsuyama \& Matsochita, 1995, 127-129).

Let us assume that genes not only contain codes that work as a generator and thus form leaves, cells, lungs, brain (Lesmoir-Gordon et al. 2000, 43-44) or even behaviour (Liebovitch 1998, 12), but that certain characteristics of genes - like stability, reproduction, and the need for nutrients, reciprocity, and growth - act as generators (first movers) for fractal patterns as well. In both cases, the environment acts as the initiator. The fractal pattern can then be recognized in cells, organisms, groups, and even nation-states.

A gene in a chaotic environment will attract molecules and will create complex structures. In this way genes that work together can create cells. Cells that additionally form organisms (i.e. humans), that in their turn can form groups (i.e. tribes or nations). Groups that eventually can cooperate within nation-states - states that have come to work together on a global scale with aid of treaties. Every level provides more safety and resources for gene reproduction (Gommer, 2011, 22-23; Gommer, 2011a; figure 2).

We can subsequently predict that organisms, groups and states will enhance reproduction, stability, need for nutrients, reciprocity and growth. Molecular properties are the cause without purpose. Rules are a means to work together in large groups. People generally experience these rules as 'normative', as 'ethical', even as being of a 'higher level' than facts, but even so, these rules are products of evolution. We, that is, our brains, formulate them because they help our genes to spread.

The urge to reproduce and to survive is a necessity for every living organism. Many organisms will act in a way that will 'automatically' enhance the spreading of the underlying genes. This is especially the case when those organisms have a lot of genes in common, like ants and bees. Body cells that have $100 \%$ of their genes in common will cooperate optimally (Wilson, 1971). However, human groups at best share $50 \%$ of their genes (in case of families) but mostly share less (in case of all other groups). Within these groups norms and morals are necessary to keep cooperation high. As these groups seek to cooperate with other groups, they need rules to attune their interests and eventually become states. In this way every level has its own coordinating system.

This biological law theory fits to the development of western law systems as was shown in 'The Molecular Concept of Law' (Gommer, 2011a). This article will interrogate whether it will stand the test when it is applied to traditional Australian Aboriginal society and law, with its complex systems of kinship and reciprocity. Close examination of classical (pre-European contact) Aboriginal society will show that four characteristics of genes, reproduction, stability, need for food and reciprocity are embedded in their law to an extraordinarily refined degree. Growth, however, was limited. It can be argued that prior to European colonisation of Australia, Aboriginal societies evolved through the sociobiological stages to the 'tribal level' and stabilised at that point for tens of thousands of years, refuting the genetic priority of growth that generally leads any given group to dominate and assimilate others.

However, this contradicts biological law theory. On a tribal level organisms will still strive for expansion at the expense of other tribes. Biological theory predicts that even cooperation of tribes on a state level will lead to growth 
of the number of individuals. How can this be explained? More, can Aboriginal culture give us a glance at future global law? To answer this question we will discuss Aboriginal culture from the perspective of five named characteristics of genes: reproduction, stability, need for food, reciprocity and - most important for our question growth. But before we come to that, we need to describe the Australian Aboriginal system for international readers that are unfamiliar with it.

\section{Aboriginal Law - An Introduction}

Morality and law were deeply intertwined in Aboriginal society. (Note 1) As Baptist minister Rev J Whitbourn submitted to the Australian law Reform Commission (ALRC, [103]):

'I found a tremendous depth of feeling in all discussions relating to their traditional law. It is so patently clear that traditional law is much more than simply matters of crime and punishment. The term 'law' is quite inadequate in fact ...[R]ather it is ... a way of life completely governed by a system of beliefs...'

This fact is in line with biological law theory which also states that law evolves from morals when people try to translate their moral conviction into rules (Gommer, 2011, 53-74). This leads to the prediction that morals, beliefs and convictions are at the basis of every law system, including Aboriginal society. One will then expect that the forenamed characteristics can be recognized in these beliefs. A brief assessment of classical Australian Indigenous legal systems and social structures should confirm this assumption.

The term 'tribe' is considered problematic by anthropologists (Keen 1988), and it is generally considered preferable in Australia to classify Aboriginal society in terms of language groups. Language groups traditionally consisted of 300-500 individuals, subsisting directly as hunter-gatherers within a specified area recognised as belonging to that language. Daily life was usually spent in small family bands, with regular gatherings of the greater language group taking place for legal/ceremonial purposes. Larger ceremonial/legal/social gatherings also occurred involving several neighbouring language groups and were often upwards of 1000 people. While the content of laws varied from language group to language group, the overall structure and approach to law was relatively consistent across the continent (ALRC, [37]).

It is now widely accepted that Australian Indigenous law is a holistic natural law system encompassing all aspects of kinship, religion, and social obligations as well as matters Western cultures would consider property or criminal law (McCrae et al., 2009, 69; Trees, 2004, 215; Bell \& Ditton, 1980, 15).

However at colonisation, the assumption on behalf of colonisers was that because Aboriginal people did not use architecture, agriculture, or authority structures recognisable to the British that they were therefore without law. Aboriginal Australians were not recognised as having law at colonisation according to British legal thought at the time (Blackstone, 1765-1769, 104-105). As a result Australia was treated as terra nullius (land belonging to no one), and therefore British settlement automatically imported British law. For legal purposes, Aboriginal people were alternatively subjected to a British law they did not understand, or treated as part of the native fauna (animals) of the continent (State Government of Victoria, 2001). Note that while Aboriginal people were technically entitled to the protection of British law, the reality of colonial conflict and lack of supervision made this unenforceable. Aboriginal people were treated as an out-group against whom violations could be committed with little threat of prosecution (ALRC, 1986, [41-42]). Aboriginal law was stripped of recognition under the conquering regime causing Aboriginal people to suffer a 'dramatic and irreversible transformation from... autonomous hunter-gatherers to being a fourth-world people living in neo-colonial circumstances' (Musharbash, 2010, 286). Even today, Aboriginal living conditions are among some of the worst in the world with many people living in makeshift shelters or car bodies (ABC, 2009). (Note 2)

It is therefore important not to fall into similar errors. For example, it could be posited that Aboriginal society, in which moral judgements for wrongdoing were often made with extensive processes of discussion and consensus building, and in which authority was held by elders who had garnered sufficient knowledge and respect (ABC, 2010), (Note 3) could be classified as existing at the third sociobiological stage of moral development in which in-group membership is determined by reputation (Gommer, 2011, 39). However, this would seem unsatisfactory, as Aboriginal law was considered fixed, often harsh and only the appropriate application, rather than its content, was open to interpretation (NTLRC, 2000, 56). Aboriginal law has now been accepted as a mature system of law by high judicial authority. As Justice Blackburn stated in Milirrpum v Nabalco Pty Ltd:

'The evidence shows a subtle and elaborate system highly adapted to the country in which the people led their lives, which provided a stable order of society and was remarkably free from the vagaries of personal whim or influence. If ever a system could be called "a government of laws, and not of men", it is that shown in the evidence before me.' (Note 4) 
It should be noted that this decision explicitly rejected the positivist assertion by the Northern Territory's Solicitor-General that law must emanate from a sovereign. This decision therefore is more likely in line with natural law theory. We also have to conclude that Aboriginal society existed at the very least at the fourth sociobiological stage of moral development in which the majority of the population abide by legal rules and sufficient disincentive to free-ride is enforced (Gommer, 2011, 84). We will examine the legal expression of the aforementioned genetic priorities in Aboriginal law, focusing on kinship law and referring more broadly to totemism. The two are intertwined and it is somewhat artificial to discuss them separately. However, they have been teased apart for the sake of analysis. The kinship discussion will deal primarily with rules and sanctions relating to the gene characteristics, and the totemism discussion will discuss the unifying worldview which, it is argued, underpins the moral and legal success of classical Aboriginal society.

\section{Expression of Genetic Priorities}

\subsection{Reproduction}

According to biological law theory, replication is an essential characteristic of genes and should therefore be recognizable as a driving force in every society and law system. In the Aboriginal law system this is indeed the case. The system enhances genetic diversity. Marriage as a lifelong contract of reciprocal obligation between families enhances the changes of the survival of offspring (ALRC 1986 [37]).

Aboriginal Australia was characterised by small numbers of people inhabiting relatively large tracts of land. The overall population of Australia prior to European settlement is estimated to have been somewhere between 300,000 and one million (Australian Bureau of Statistics 2002). To enable maximum genetic diversity, Aboriginal societies developed an elaborate law of kinship now recognised as 'among the most complex on Earth' (Rose, 2003, 53). This dictated who could marry whom and defined general rights and obligations (ALRC, [37]), and is often referred to as the 'skin' system (Beckett, 1967, 458).

The skin system involves classifying every person as a member of the same extended family and within it, 'all sociality assumes the form of kin relations' (Austin-Broos, 2003, 120). For example, all of one's father's brothers are also considered to be one's father, and all ones mother's sisters are also considered to be one's mother (Becket, 1967, 458). All children of one's father's brothers and mother's sisters (parallel cousins) are considered siblings (Morphy, 2006, 25). Relations with such 'siblings' of the opposite sex are formal and may be characterised by avoidance rules (Becket, 1967, 459-460). Cross-cousins (children of father's sisters or mother's brothers) are classified differently. Relatives by marriage are also classified as blood relatives giving 'the widest possible recognition to genealogical relationships' (Keen, 1988, 80). People were treated as close relatives even when genetically unrelated (ALRC, [337]). This greatly extended community obligations to care for children as all 'effective kin' were involved in child-rearing (ALRC, [230], [344]). This ensured that even when a woman could not support her own children they had the best chance of reaching maturity (ALRC, [289]).

Within the skin system, people were divided into two moieties, and from there into four or eight subsections (Musharbash, 2010, 227; Bradley, 2007, 25). The skin system ensured that marriage partners were distributed evenly between moieties (Radcliffe-Brown, 1930, 37-38) and in most systems one was expected to marry the most distant relative available being someone classified as a second cousin (Musharbash, 2010, 274; Radcliffe-Brown, 1930, 34-63, 206-256, 322-341, 426-456)), preferably from the opposite moiety (Bradley, 2007, 26). Marriage to actual second cousins was generally but not universally prohibited (Becket, 1967, 456). All other marriages were prohibited as they equate to marrying someone socially regarded as one's parent, grandparent, niece/nephew, parent-in-law, uncle/aunt or grandchild (Musharbash, 2010, 276). Marriages were arranged, and involved a lifelong contract between families involving both the provision of food and legal processes (ALRC, [233]). For example, among the central Australian Warlpiri, a man who initiates a boy, providing him with the path to legal majority, will later betroth his sister's daughter to the same man (Musharbash, 2010, 274). This may happen in the infancy of the girl concerned and from the betrothal until the marriage, the groom will provide food to the girl's mother. Law dictates he must avoid any other interaction with her, as the food-giving relationship resembles marriage and such avoidance rules therefore 'prevent the arising of an incestuous relationship and protect the interests of her husband' (Keen, 2010, 102). Some 90\% of marriages conformed to the skin system and are termed 'right-way' marriages.

Even today there is a widespread observance of these marriage rules (Musharbash, 2010, 276-278). 'Right-way' marriages entitle current and future generations to rights and responsibilities over land (Musharbash, 2010, 281). Sanction for 'wrong-way' marriage can be harsh. People who marry 'wrong-way' may suffer extensive ostracism and even banishment (ALRC, [454]). Children of 'wrong-way' unions suffer uncertain lives as there is no place for them in the legal cosmos and it is unclear who is responsible for their education, welfare or discipline (McGrae, 2009). 
Of particular note is what Musharbash calls the 'moral universe' of sexual relations. There existed, and still exists, tolerance of adultery and romantic or even casual sexual relationships as long as the liaison remains 'right-way' within the kinship system (i.e. with a classificatory second cousin) (Musharbash, 2010, 280). Social fatherhood is accepted for children born to men other than the husband, as long as the partners are discreet and the husband not publicly humiliated (Musharbash, 2010, 279). Fidelity to one's partner is not considered as important as fidelity to the skin system and censure is more for violation of kinship norms than for adultery per se. As Musharbash states, 'right and wrong do not refer to the kind of relationship (marriage, affair or casual sex) but to the classificatory kin relations between the partners concerned' (Musharbash, 2010, 280). Classical Aboriginal culture therefore provided an outlet for those in contractual and potentially loveless arranged marriages while still ensuring optimum conditions for reproduction in a small gene pool and was 'extremely tolerant in terms of the intense force of emotions such as love, lust and desire in people's lives'(Musharbash, 2010, 280-281).

\subsection{Stability}

The next important property of genes is that they have to be stable to spread. According to biological law theory, stability will thus be a characteristic of societies that is enhanced by law. In the Aboriginal Law system there are indeed many prescriptions that enhance group stability.

Stability in classical Aboriginal society is achieved by what Sercombe describes as a 'moral economy' of sharing in a complex reciprocal system intimately connected to the skin system, and still observable among Western Australia's Wankai (Sercombe, 2008, 19). This spreads risks and cushions society against the irregular supply of food and goods (Blainey in Sercombe, 2008, 19), and will be discussed further below. Stable groups will not permit individual group members to profit by their own fraud (Gommer, 2011, 69; Riggs v. Palmer, Court of Appeals New York 1889). Aboriginal customary laws are as much a process for the resolution of conflict as a system or set of rules (ALRC, [202]), and an extensive system of sanctions exist for breaches of law, many of which are punishment for failing to meet reciprocal kinship and ritual/legal obligations (ALRC, [696], [707], [717], [835]). Sanctions include public admonition, ridicule, banishment, compensation and in some cases spearing.

Stability was also protected by the distribution of power which was decentralised in a number of ways. For example, land and resources were managed by an owner/guardian system (Bradley and Yanyuwa Families 2007, 26). Any given tract of land, sacred site or resource, had an 'owner' under the kinship system, and a counterpart from the opposite moiety who took a 'guardian' role. Every owner of one area was also guardian of another and vice versa. Owners cannot make decisions without consultation with the opposite moiety's guardian, thereby ensuring the equitable spreading of resources (Musharbash, 2010, 26). Further, sanctions for breaches of law were not under the control of a central person or body. Punishment could only be meted out by those who in the correct skin relationship with the offender, usually the maternal uncle, as with the Maljangaba of Northern New South Wales (Beckett, 1967, 459-460; ALRC, [456]), in consultation with those affected by the offence and pursuant to a meeting the relevant elders (ALRC, [247], [708]). Certain other relatives were entitled to intervene to plead on the offender's behalf, usually the offender's maternal parallel cousin (Beckett, 1967, 459-460). Even the most powerful person in a given moiety could only speak for the members of that moiety, so even a particularly charismatic individual could not gain effective control of more than half the population (Blagg, 2008, 84-85). This ensured the need for ongoing cooperation within the language group. It should be noted that this system also secures checks and balances, which can be considered - rather than the separation of powers - a basic notion in cooperation within groups (Gommer, 2011, 108).

Legal sanctions in Aboriginal societies are closely aligned with the need to satisfy the emotional needs of an outraged community, and this supports the theory that punishment is an expression of a society's emotional response to a crime (NTLRC, 2005, 156-157). As Bell and Ditton $(1984,114)$ state '[ L]aw ... has to do with peace maintaining strategies, resolution of conflict mechanisms and the ability to enter into and sustain correct relationships with one's kin and the country of one's ancestors.' Punishments were negotiated promptly and carried out while people's 'blood [was] hot' (ABC, 2010). To prevent conflict escalating, serious punishments such as spearing in the leg (a classical punishment for murder) were conducted in a controlled environment in the presence of all group members and elders had the authority to intervene (NTLRC, 2005, 25). Punishments, once meted out, were considered to settle matters entirely, allowing normalisation of relationships and the continued stable functioning of society (Blagg, 2008, 165). It is argued that this system of power-sharing and community involvement in the negotiation and carrying out of justice was a central part of creating and maintaining group stability, ensuring that all members were enfranchised and satisfied with legal outcomes.

In short, as in western legal systems, stability in Aboriginal society is provided by checks and balances and the punishment of free riders. Punishment fulfils the need to assuage community outrage, as can be observed in Western 
countries such as the Netherlands (Gommer, 2011, 157-159). Aboriginal people were more enfranchised as a result of direct input in small societies with localised law enforcement, rather than the remote power of the state that leaves many Westerners feeling alienated from the process of law-making and application.

\subsection{Need for Food}

As genes only spread if there are enough molecules to create a replicated gene, the need for food is also an important characteristic of genes. Organisms, groups and society will therefore have to provide extra food for individuals and underlying genes in order to perpetuate themselves and spread. In the harsh Australian environment the availability of food would logically be an important aspect of law.

The Australian environment with its irregular rainfall, poor soils, cyclical drought, flooding and bushfire (see DFAT, 2011) is not well-suited to sedentary agriculture, which has suffered considerable instability and a progressive degradation of over-farmed land from colonial times though to the present era of technological agro-industry (Rose, 1996, 76-79). Traditionally, seasonal native food was available in various locations year-round, but access required constant movement (Sercombe, 2008, 19). Aboriginal people maintained a hunter-gatherer lifestyle that allowed movement across language group estates to benefit from seasonal resources, and managed their territories with a detailed regime of controlled burning sometimes termed 'firestick farming' (Rose, 1996, 63-67). This attracted game animals by stimulating fresh plant growth, kept the landscape clear for hunting and reduced the risk of death or resource decimation by wildfire.

Access to food was intricately bound up with kinship relationships which dictated obligations for sharing (ALRC, [224]; Sercombe, 2008, 25). One had to have recognised kinship ties to be entitled to access food or resources in a given area (McConvell, 1998, 180-186). Marriage permitted access to the land and resources of close relatives of one's spouse (Keen, 2010, 103). People were also entitled to make claims to country (and therefore food) on a range of grounds including the locations of important events such as conception, initiation, birth, father/mother's conception, residence and the site of the death of a close relative (Keen, 2010, 104). The 'moral economy' of reciprocity based on kinship with a 'focus on distribution and exchange' was a 'highly adaptable' mechanism for sharing food and ensuring that the maximum amount of people were adequately nourished (Sercombe, 2008, 19-20).

In short, Aboriginal groups are organized in such a way that access to food is optimized. Food is shared with genetic relatives and in-group people, as Alexander predicted $(1987,84-88)$ as was the case in earlier research amongst Dutch people (Gommer 2011, p. 130-159).

\subsection{Reciprocity}

As mentioned, reciprocity is a fundamental to the 'success' of genes (Rose, 2000, 64; Hamilton, 1963, 353-355; Alexander, 1987, 85). Thus, following biological law theory, reciprocity should be an important aspect in every law system.

According to Sercombe $(2008,20)$, in the 'Aboriginal moral economy', the focus is not on the value of items exchanged but on the reinforcement of reciprocal bonds. In Aboriginal law, reciprocity was expressed through kinship (Rose, 2003, 1). Everything was understood through the prism of relationships (Bradley, 2007, 807) and 'relatedness is at the basis of the Law' (Bradley, 2007, 22). It is generosity, not wealth which determines social status (Sercombe, 2008, 19). Peterson maintains that a system of 'demand-sharing', in which kinship ties give the right to ask and be provided with needed resources, is central to the success of this economy (in Sercombe, 2008). In a semi-nomadic context, accumulation of goods or food is useless as the surplus cannot be carried and so distribution and resultant reciprocal obligation is a more logical way to deal with the excess (Blainey in Sercombe, 2008). As Sercombe states, in an environment where daily production was unpredictable 'the customary economy manages this risk (in a similar way to insurance policies) by averaging it out across the economic unit'.

In the demand-sharing system, people can access anything they need from the appropriate relative. However, in such a system, free-riding will be attempted and sometimes achieved. Group members must develop the ability to reject spurious demands from those not truly entitled and children must be taught whose claims are legitimate and whose are not (Sercombe, 2008, 22-24). Greater generosity in demand sharing is expected with closer relatives, whereas exchange with distant relatives of the opposite moiety were better characterised as trade in which value was given for value (Becket, 1967, 460). It is believed that when resources were scare, priority was given to kin through marriage (Tibbet, 2004, 9).

Reciprocity in traditional Aboriginal society not only concerns food and goods but also involves services and legal obligations (ALRC, [328]). For example, one's patrilinieal moiety provides ceremonial and hunting rights, while one's matrilineal moiety provides marriage partners (Radcliffe-Brown, 1930, 35). Traditionally, child-rearing was reciprocal over time where a child's mother and close kin provided care for infants and the father's kin took 
responsibility for education of older children. Parallel cousins support one in disputes, but are not obliged to share the best food. On the other hand, cross-cousins may be generous with both food and training. Discipline of children and punishment of adults is the responsibility of the mother's brother, who is also responsible for the betrothal of girls and the initiation into manhood of their future husband, as described above. A young man in receipt of these services will be indebted to this uncle for life. Conversely, the cross-cousin who guides a boy through the process of initiation forms a lifelong bond of support and friendship with him (Becket, 1967, 459-460).

Provision was made for the individual's varying capacity to contribute according to notions of reciprocal altruism. For example, the Arrernte (central Australian) general norm was for the less powerful to work for the more powerful while the latter should look after them in exchange (Austin-Broos, 2003, 120). Reciprocity extended beyond the family or language group and extensive trade networks existed throughout Australia (ALRC, [325]). Entire language groups would engage in reciprocal sharing of abundant seasonal resources such as bunya nuts and spawning fish (Tibett, 2004, 7). Gift-giving was also employed as a method for resolving disputes, as committing a wrong against someone created an obligation (ALRC, [328]). It is submitted that this reciprocity within a system that encompasses all members of society as family is the key to the success of Aboriginal law as a discrete and sustainable legal system. This coincides with the theory that legal systems are a means to expand reciprocity within families and tribes to nations. Law is a means to create cooperation between groups in order to decrease violence and to enhance stability and sustainability (Gommer, 2011, 130).

\subsection{Totemism}

Before we go on to describe growth in Aboriginal society, it is necessary to address totemism as a device for expanding the principle of reciprocity. Expanded reciprocity seems to be a key to sustainable growth and stability in an environment that is limited.

As Rose et al. $(2003,6)$ state, totemism can be seen as 'a system of connectivities between humanity and nature... of classification..., responsibility, and shared physical substance....a non-random relationship between particular humans and particular non-humans'. The history of Western scientific thought since the rise of Darwinism has been characterised by the notion that totemism separates 'civilised' societies (who consider themselves to be separate from nature) from 'savage' societies who do not (Rose et al., 2003, 6). Totemistic societies, therefore, were considered to be less evolved than Western societies and is posited that the central role of totemism in the legal success of Aboriginal societies has as a result generally been overlooked.

Where Aboriginal law distinguishes itself most from Western law is that it extended the system of kinship-based reciprocity not only to all human members of society, but also to other species and even the landscape (Rose, 2003, 56). Warner described totemism as 'a system of ritual relations between clan members and certain species of plants and animals (Rose et al., 2003, 9).' Not just humans, but other species and even territories were granted personhood and a right to moral treatment (Rose, 2003, 56). This moral economy was enlivened and maintained through reciprocity. For example, when Yuin women saw bark peeling from certain trees (an annual event that coincides with fish running or eels being ready for harvest) those trees were seen as helping the women by telling them that food would be abundant in the river. Yuin men, in turn cared for these trees by singing songs to them that they were believed to be fond of (Rose et al, 2003 48). A further spur to right action lay in the fact that moral awareness was also considered to be reciprocal, the land and its non-human inhabitants being conscious of human actions and capable of making value judgments about them (Rose, 1996, 70).

To give a broader example, each language group was considered to be responsible for a major species or function of the natural world, and had obligations to care for its perpetuation not only for their own sake but for the sake of surrounding groups. For example, as Rose et al. $(2003,12)$ describe, one language group may be responsible for creating rain, and a neighboring group for kangaroos. As both need rain and kangaroos, they are interdependent and reciprocity between groups is extended to the husbanding of natural resources. Kangaroo people are also responsible for ensuring no hunting occurs in sacred kangaroo sites and 'practices of restraint' are considered 'as important as success in hunting'. These places correlate to permanent sources of feed and water for kangaroos that enable the species to survive periods of drought and scarcity. The successful survival of drought by kangaroo populations then benefits people, so a reciprocal relationship between human and non-human is given legal and enforceable form. In addition, people from other regions who share the kangaroo totem are considered kin, even if genetically unrelated (Rose, 2003, 55).

Language can serve to communicate group morals, and to tell other members what is expected of them. Thanks to language, morals can be put into words and rules can evolve. But morals can also be communicated in stories that reflect common truths about human nature that each society expresses in its own way. According to James Ridgway (2010), these stories can show a way to improve cooperation, cooperation that will improve growth. From this 
perspective, law is a 'specialized tool for resolving these narratives into rules for handling complex problems of cooperation.' Thus the function of the law can be achieved by stories that enhance cooperation by triggering certain emotions (Gommer, 2011, 71). In Aboriginal culture this connection is very clear. For Aboriginal people, stories were the source of law that created the powerful connection between people and territory and delineated what their rights and responsibilities were (Musharbash, 2010, 21-23). These 'moral, jural and social rules' are derived from the action of ancestral beings capable of taking both animal and human form, who travelled the landscape, gave life to people in specific locations, allocated their territory and educated them in all aspects of lawful behaviour. These rules are reinforced by daily practise and ritual observance. People who identify with a particular spirit ancestor are considered kin even if genetically unrelated (Musharbash, 2010, 23).

Kinship links were thus also established between people and places, animals and even non-living objects such as tools. Every tract of land was associated with a particular clan within a language group, often in interlocking alternating patterns (Bradley and Yanuwa Families 2007, 23). This system extends even to plant and animal species which are regarded as having kinship relations with each other where a reciprocal relationship exists, such as between an animal and its foodstuff. All other species are seen as having their own 'Law' (ways of doing and being, territory, legal ceremonies and the ability to perceive and make value judgements about human beings etc) which humans can observe and learn from, instilling respect into dealings with all aspects of the natural world. As Bradley states, this takes the form of 'a non-human-centred moral ecology premised on attributions of intentionality, obligation, responsibility and reciprocity' (Bradley and Yanuwa Families 2007, 24).

Put simply, significant species and places, natural phenomena and spirit ancestors were also included in the skin system and were therefore considered to be one's self, brother, sister, mother, grandmother, etc. (Bradley and Yanuwa Families 2007, 22-25). For example, one's mother's totem was also considered to be ones mother, as was the ancestral being associated with that totem animal. Such a person stands in the position of child to the land that is classed as belonging to their mother's spirit ancestor and has a deeply emotional relationship to it. In the owner/guardian system described above, they are the guardians for both 'mother's country' and related animals and their presence is required to even visit certain places as they are the only people seen as able to negotiate entry with the powerful natural forces residing there (Bradley and Yanuwa Families 2007, 24-27).

People will invest less in non-kin than in close kin, and even less in other species (Gommer, 2011, 134). It can be seen that this reciprocity-based kinship system and associated totemism allows Aboriginal society to expand the in-group to include not only the maximum amount of people but the very species and natural resources necessary for survival. This worldview enables people to live in a state of potentially indefinite sustainability as the in-group is virtually expanded to all living creatures that are indispensable for future reproduction.

\subsection{Growth}

Genes that spread through the environment have a bigger change to survive over the ages. Therefore, growth is an inherent characteristic of genes. As a consequence, society will have the predisposition to grow. However, as can be derived from the foregoing paragraph, in Aboriginal society the focus was not on growth of populations, but on their maintenance (ALRC, [223]). The central economic logic was not accumulation as with capitalist societies but subsistence and shelter (Sercombe, 2008, 19). Australia's variable climate and often harsh environment limited the optimum number of people who could subsist sustainably from the landscape and reciprocal systems allowed a greater population to be supported by evening out the availability of food and lessening the effects of drought (Tibbett, 2004, 8). It is interesting to note that while Western family trees, like most animal family trees, are represented as an ever-expanding fractal, that graphic representations of skin systems instead show a closed system which cycles through the generations, folding its members into a repeating, but not expanding pattern. In this way, the existence of underlying genes is guaranteed, although these genes will not grow in number because of the limited food supply.

Human growth is limited not only by the limits of available food, but also by the practicalities of child-rearing. Sympathy for non-kin is also a disposition to secure the nurturance of children for the long period that is needed to let the brain fully develop (Wilson, 1993, 1-12). A comparison of the weight of chimpanzee babies, babies of Australopithecus, and human babies, showed that a baby of the Australopithecus was much heavier than a chimpanzee baby (DeSilva, 2011, 1022-1027. This fact had serious implications for behavior. Mothers no longer could carry their children into the tree if they had to flee for hostiles; they became much slower. Consequently, mothers and their children needed more protection, and finding food was more difficult. Common upbringing by community members became a benefit. In a semi-nomadic society there is an extra limitation, for any given woman can only carry one infant. Children must be spaced out so that the older one is capable of independent travel before a younger one is born. As Aboriginal people had inhabited Australia for tens of thousands of years and spread both 
their genes and their legal system to all but the most uninhabitable parts of the continent, it can be assumed that their numbers represented an optimum population for what the land could sustain in the long term. As Leibig's Law of the Minimum (as restated by White) affirms: 'biological populations are limited, not by the minimum amount found at the scarcest time of a typical year, but by the minimum amount found at the scarcest time of a bad year" (Tibbett, $2004,8)$. Rules of reciprocity prevented any group from hoarding resources at the expense of others, and the theory that law should reflect reciprocity and thus benefit the whole society was clearly expressed as is demonstrated above. If populations become unsustainable they inevitably collapse (See generally Diamond, 2005). It is argued that Aboriginal people developed a legal system that allowed them, in the main, to stay within the nutritional limits of their environment and to do this sustainably. Reciprocity rules appear to be the main legal strategy by which the genetic priority of growth has been curbed, as in the example described above where refraining from hunting in order to protect the breeding and survival sites of significant species was incorporated into one's legal obligations (Rose, 2003, 12). In this way, the legal system served the survival purposes of the underlying genes. It seems probable that this 'restrictive' system evolved without knowing this would serve these genes. As an effect, the need to limit growth within an environment with less nutrients seems to evolve eventually in a natural environment.

\section{Aboriginal Global Cosmology}

The absence of the familiar machinery of states and nations makes it a simple matter to consider Aboriginal society as having stabilised at the fifth 'tribal' level of reproduction facilities for genes and sociobiological stage of moral development in which there are not yet 'secondary rules'. However, application of Aboriginal law extended to protocols regarding negotiation and conflict within and between language groups, where there were numerous ways of resolving disputes and promoting peaceful solutions rather than resorting to armed conflict. For example, in Northern Australia disputes were settled by symbolic fighting at large meetings known as prun (Breen, 2007, 11). This implies that there was embedded in Aboriginal law something analogous to a set of secondary rules that governed relationships and was administered and applied at ritual gatherings. As Blackburn stated in Millirpum:

'The specialization of the functions performed by the officers of an advanced society is no proof that the same functions are not performed in primitive societies, though by less specially responsible officers. Law may be more effective in some fields to reduce conflict than in others, as evidently it is more effective among the plaintiff clans in the field of land relationships.' (Note 5)

While small skirmishes and reprisals were relatively common within and between language groups, actual warfare was rare, and interestingly was never waged over territory (Breen, 2007, 11). Boundaries were permeable but respected (Rose, 1996, 9). Only when the numbers of a particular group declined beyond a sustainable level, would a neighboring group with close kinship ties absorb their territory in a guardianship role (Note 6). This lack of territorial disputes or interference with each other's resources displays a legal stability and a respect for the sovereignty of neighbours that many nation-states would envy. The kinship laws that have such deep moral weight appear to be the secret to curbing growth, both in relation to the sustainable use of resources and in preventing one group from dominating others. As Peterson (in Rose, 2003, 10) maintains, totemism is 'a mechanism for ordering sentiment toward home place and ... a key mechanism in territorial spacing'. Conquest was rare as there was no logic and considerable stress and discomfort in attempting to live in a place that one has no kinship ties with and in which one could not 'fit' (Rose, 2003, 56). As Rose $(2003,58)$ states, for Aboriginal people 'The position of being a stranger is... barely tolerable'. Boundaries, kinships and totem relationships were in addition held to have been laid down by ancestral beings and had the force of sacred law.

As has been demonstrated above, risk-spreading through co-operation and reciprocity allowed Aboriginal people to spread their genes over an entire continent and its outlying islands, and then achieve a political stability in which no one group sought to overrun the other. Biological law theory holds that a globalisation in which states work cooperatively to address challenges and allow all participating parties to prosper in an environment otherwise non-conducive to stability is the highest level of legal organisation available to mankind (Gommer, 2011, 22). An interesting proposition is that classical Aboriginal society, in establishing such stable rules of jurisdiction, conflict resolution and reciprocity had at some time in its 40,000 year history proceeded through the treaty stage to the global community stage within the boundaries of the continent that formed the Aboriginal cosmos. The delimitation of the agreements regarding boundaries and jurisdiction were encoded in sacred mythological law. It remains unclear how this stage of a 'global community' on the Australian continent was reached. There is evidence that in the late Holocene around the Lake Eyre basic some areas, food-sharing had become so effective that alleviating the effects of drought that populations were growing and that competition for food had shifted from reciprocity to 'negative reciprocity' or trade, where groups had to compete to offer the best bargain to access finite resources, thereby defeating the purpose of the original risk-minimisation strategy (Tibbett, 2004, 7-9). This economic development was interrupted by colonisation. Whether this was a unique phenomenon or a cycle that had been 
repeated many times over generations until scarcity or drought again reduced the population is not known. However, what can be learned from Aboriginal law is that expanding the in-group radically seems to be necessary to reach a balanced and sustainable society in a world were resources are scarce. This knowledge could prevent us from cycling through eras of extinction and growth before an equilibrium is reached.

It is interesting to note that since settlement, Aboriginal society in some ways has returned to the treaty stage. There are constant efforts on behalf of both Indigenous and non-Indigenous to engage the Australian nation with the idea that a treaty with the Aboriginal inhabitants is both morally desirable and politically necessary. Changes are currently being proposed to the Australian Constitution that may open a way for "agreements" to be made with indigenous people. - This could provide a platform for a treaty in the future, but it remains a highly charged and contentious political issue with strenuous opposition from some quarters of Australian society and it may be some time before such agreements are possible. (Note 7) Because Western society has not yet developed to the seventh stage of global law Aborigines must engage with the Australian Government at the sixth level of treaty-making. Attempts are being made to access international structures such as the United Nations International Committee for the Elimination of Racial Discrimination in the attempt to preserve their society from legal colonisation (Kacha, 2010), but these agencies have only at best a moral power to influence the Australian nation. Aboriginal society, being subject to great social and legal disadvantage is genetically threatened by the Australian state, and Aboriginal legal systems are now in danger of permanent annihilation (Blagg, 2008; Cunneen, 2001; McCrae, 2009). If Western legal systems were superior to Aboriginal law in showing a way to future stable and sustainable society, this probably would not have implications for mankind's future beyond its own inherent tragedy and injustice. However, as Western society has not yet developed a legal system that is sustainable in a finite biosphere and in which all world citizens are equally provided for, it would be a great loss for global citizens for this example of a stable law system in an environment of limited resources to be lost. By learning from the Aboriginal system, we could more quickly enter the stage in which we have adapted to limited resources.

\section{Conclusion}

Due to a harsh environment and geographical isolation, the genetic property of growth was successfully curbed by Aboriginal law to operate indefinitely and sustainably within a finite biosphere. Extensive rules of reciprocity, a totemic worldview that extends immediate kinship to many aspects of the natural world and some kind of global law would appear to be the key to a sustainable way of life, which was legally and politically successful for tens of thousands of years on an isolated continent with scarce resources. This was disrupted by a Western society at the stage of conquest and formation of primary and secondary rules at a state level. Obviously, in a world of plenty, this was an effective way to spread the genes of Western group members, but it brought untold injustice to Aboriginal people in Australia and elsewhere. In a world of globalisation and depletion of natural resources, a rapid expansion of the in-group to include all people in the world is indispensible if we want to reach a new equilibrium. The genetic drive for growth will ultimately exhaust our resources and defeat the genes of many of us if we do not find a way through our law to steer it. Ultimately the dilemma we face on a global scale is the same as that solved on a continental scale by Indigenous Australians. Central to the success of Aboriginal law was the ability to use law to curb the genetic property of growth by elaborating the genetic property of reciprocity, and much could be learned from Aboriginal legal systems in facing our own environmental and social dilemmas.

\section{References}

Alexander, R. (1987). The biology of moral systems, New York: Aldine de Gruyter.

ALRC, Australian Law Reform Commission, (1986), Recognition of Aboriginal Customary Law.

Austin-Broos, D. (2003). Places, Practices, and Things: The Articulation of Arrernte Kinship with Welfare and Work, American Ethnologist, Vol. 30, No. 1, 118-135. http://dx.doi.org/10.1525/ae.2003.30.1.118

Australian Bureau of Statistics, (2002), Aboriginal and Torres Strait Islander population, Year Book Australia 2002.

Barnsley, M.F., J.E. Hutchinson \& Ö. Stenflo. (2004). Variable Fractals and Superfractals, Australian National University.

Beckett, J. (1967). 'Marriage, Circumcision and Avoidance among the Maljangaba of North-west New South Wales', Mankind, Vol. 6, No. 10.

Bell, D., \& Ditton, P. (1984). Law: The Old and the New. Aboriginal Women in Central Australia Speak Out, Canberra: Aboriginal History, 114.

Blackstone, W. (1765-1769). Commentaries on the Laws of England, Vol. 1.

Blagg, H. (2008). Crime, Aboriginality and the Decolonisation of Justice, Hawkins Press. 
Bradley, J., \& Yanyuwa Families. (2007). Barni-Wardimantha Awara Yanyuwa Sea Country Plan, Mabunji Aboriginal Resource Association.

Breen, H. (2007). Visitors to Northern Australia: Debating the history of Indigenous gambling, in: McDonnell, S. Grabowski \& R. March (eds), Tourism - past achievements, future challenges: Proceedings of the 17th Annual Cauthe Conference, Sydney, NSW, 11-14 February, University of Technology Sydney, Sydney: NSW.

Cunneen, C. (2001). Conflict, Politics and Crime: Aboriginal Communities and Police, New South Wales: Allen \& Unwin. DFAT, Department of Foreign Affairs and Trade, (Australian Government) Australia's Environment at a Glance. [Online] Available: www.dfat.gov.au/facts/env_glance.html

DeSilva, J.M. (2011). A shift toward birthing relatively large infants early in human evolution, PNAS, 1022-1027. http://dx.doi.org/10.1073/pnas.1003865108

Diamond, J. (2005). Collapse: How Societies Choose to Fail or Succeed, Penguin.

Flannery, T. (2002). The Future Eaters, New York: Grove Press.

Gommer, H. (2011). A Biological Theory of Law: Natural Law Theory Revisited, Seattle: CreateSpace.

Gommer, H. (2011a). The molecular concept of law, Utrecht Law Review, Vol. 7, nr. 2 (available at SSRN.com).

Hamilton, W.D., (1963). The Evolution of Altruistic Behavior, American Naturalist.

Katcha, Sabine. (2010).Re: Inquiry into the amending bills concerning the NT Intervention, Submission to the Senate Standing Committee on Community Affairs. [Online] Available: www.aph.gov.au/senate/committee/clac_ctte/soc_sec_welfare_reform_racial_discrim_09/submissions/Sub95.pdf

Keen, I. (1988). Twenty-five Years of Aboriginal Kinship Studies' in: R.M. Berndt and R. Tonkinson (Eds), Social Anthropology and Australian Aboriginal Studies: A Contemporary Overview. Canberra, ACT: Aboriginal Studies Press.

Lesmoir-Gordon. N., \& W. Rood \& R. Edney (2000). Introducing Fractal Geometry, Cambridge: Icon Books.

Liebovitch, L.S. (1998). Fractals and Chaos, New York: Oxford University Press.

Mandelbrot, B. (1982). The Fractal Geometry of Nature, Fenn and Company.

Matsuyama, T., \& M. Matsushita (1995). Morphogenesis by Bacterial Cells, in: Iannaccone, P.M. and M. Khokha, Fractal Geometry in Biological Systems. An Analytical Approach, Boca Raton: CRC Press.

McConvell, P. (1998). "Born is Nothing": Roots, Family Trees and other Attachments to Land in the Victoria River District and the Kimberleys' Aboriginal History, Vol. 22.

McCrae, H. et.al. (2009). Indigenous Legal Issues: Commentary and Materials, Thomson Reuters.

Morphy, F. (2006). Lost in Translation? Remote Indigenous Households and Definitions of the Family, Australian Institute of Family Studies: Family Matters, No. 73.

Musharbash, Y. (2010). 'Marriage, Love and Adultery: Warlpiri Relationships as seen by Three Generations of Anthropologists' Oceania, Vol. 80, Nr. 3.

NTLRC, Northern Territory Law Reform Commission (2005). Report of the Committee of Inquiry into Aboriginal Customary Law: Report on Aboriginal Customary Law

NTLRC, Northern Territory Law Reform Committee (2006). Background Paper 5: Aboriginal Customary Laws Reference - an Overview.

Radcliffe-Brown, A. R. (1930). The Social Organization of Australian Tribes. Oceania, Vol. 1.

Ridgway, J.D. (2010). 'The Three Patterns of Human Interaction: Evolutionary Biology and the Convergence of Narrative and Economic Legal Theory', (not published).

Rose, D.B. (1996). Nourishing Terrains: Australian Aboriginal Views of Landscape and Wilderness, Australian Heritage Commission.

Rose, D.B. (2000). Dingo Makes us Human: Life and Land in an Australian Aboriginal Culture, Cambridge: Cambridge University Press.

Rose, D.B. (2003). Sharing Kinship with Nature: How Reconciliation is Transforming the NSW National Parks and Wildlife Service, Centre for Resource and Environmental Studies, Australian National University.

Rose, D.B., \& James, D. and Watson, C. (2003). Indigenous Kinship with the Natural World in New South Wales, NSW National Parks and Wildlife Service. 
Sercombe, H. (2008). Living in Two Camps: The Strategies Goldfields Aboriginal People use to Manage the Customary Economy and the Mainstream Economy at the Same Time, Australian Aboriginal Studies.

State Government of Victoria. (2001).Victorian Essential Learning Standards, About the 1967 Referendum. [Online] Available: vels.vcaa.vic.edu.au/downloads/sample_units/aboutreferendum.doc accessed 09/06/2011

Tibbett, K. (2004). Risk and Economic Reciprocity: An Analysis of Three Regional Aboriginal Food-sharing Systems in late Holocene Australia, Australian Archaeology, nr. 58.

Trees, K. (2004). Contemporary Issues Facing Customary Law and the General Legal System: Roeburne - A Case Study Background Paper no 6, Law Reform Commission of Western Australia.

Wilson, E.O. (1971). The Insect Societies, Cambridge: Harvard University Press.

Wilson, J.Q. (1993). The Moral Sense, American Politcal Science Review.

\section{Notes}

Note 1. It is recognised that Aboriginal law in still operates to some extent across much of Australia. This essay primarily concerns itself with classical society law and economy, particularly the now-defunct practise of living an entirely hunter-gatherer lifestyle. For an analysis of the persistence of Aboriginal law and economy in a post hunter-gatherer context see Sercombe, 2008.

Note 2. Australian Broadcasting Commission News Online, (Anna Henderson), 'Aboriginal living Conditions "Fifth World"', 30 November 2009, available from www.abc.net.au/news/stories/2009/11/30/2757337.htm.

Note 3. ABC, Australian Broadcasting Commission, Radio National, 'Making Violence Men's Business', 14 November 2010 Background Briefing, 14 November 2010, (Bess Nungarrayi Price) available from

$<$ www.abc.net.au/rn/backgroundbriefing/stories/2010/3061479.htm>, accessed 23/03/2011.

Note 4. (1971) 17 FLR 141 at 267. Blackburn J explicitly rejected the positivist assertion by the Northern Territory's solicitor-General that law must emanate from a sovereign at 266.

Note 5. (1971) 17 FLR 141 266, 268.

Note 6. See Milirrpum v Nabalco Pty Ltd at p.27, 28.

Note 7. See Sydney Morning Herald Online, 'Chief Justice backs Aboriginal Treaty’ Joel Gibson, March 28, 2009, available from <www.smh.com.au/national/chief-justice-backs-aboriginal-treaty-20090327-9e79.html > accessed 20/06/11; Australian Institute of Aboriginal and Torres Strait Islander Studies, (2001) 'Treaty' (exhibition materials and background) available from <w1.aiatsis.gov.au/exhibitions/treaty/atc.htm> ; accessed 20/06/11, Australian Broadcasting Commission News Online 'Aboriginal Treaty Push for Summit, April 18, 2008, available from $<$ http://www.abc.net.au/news/stories/2008/04/17/2220322.htm> accessed 20/06/11.

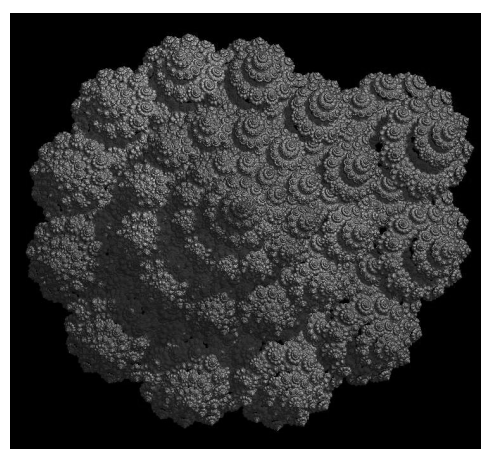

Figure 1. Fractal; Macro scale patterns mirror micro scale patterns 


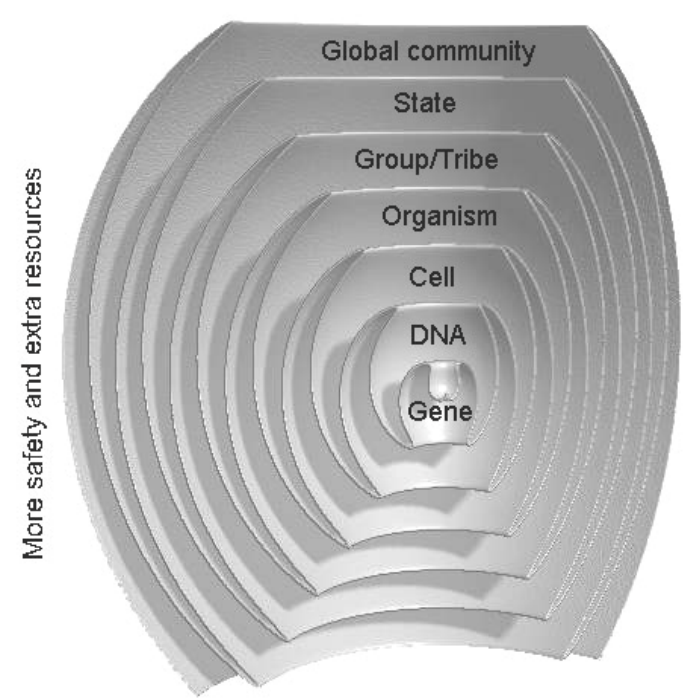

Figure 2. Seven levels of reproduction facilities for genes. Every level yields more safety and resources in order to enhance reproduction. 